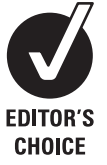

London Centre for Paediatric Endocrinology and Metabolism, Great Ormond Street, Hospital for Children NHS Trust, and The Institute of Child Health, University College London, London, UK

Correspondence to:

Dr K Hussain, Developmental Endocrinology Research Group, Clinical and Molecular Genetics Unit, Institute of Child Health, University College London, 30 Guilford Street, London WC1N 1EH, UK; K.Hussain@ich.ucl.ac.uk

Received 30 October 2008 Revised 24 December 2008 Accepted 21 January 2009 Published Online First

1 March 2009

\title{
The genetic basis of congenital hyperinsulinism
}

\author{
C James, R R Kapoor, D Ismail, K Hussain
}

\section{ABSTRACT}

Congenital hyperinsulinism (CHI) is biochemically characterised by the dysregulated secretion of insulin from pancreatic $\beta$-cells. It is a major cause of persistent hyperinsulinaemic hypoglycaemia $(\mathrm{HH})$ in the newborn and infancy period. Genetically $\mathrm{CHI}$ is a heterogeneous condition with mutations in seven different genes described. The genetic basis of $\mathrm{CH}$ involves defects in key genes which regulate insulin secretion from $\beta$-cells. Recessive inactivating mutations in $A B C C 8$ and KCNJ11 (which encode the two subunits of the adenosine triphosphate sensitive potassium channels (ATP sensitive $K_{\text {ATP }}$ channels)) in $\beta$-cells are the most common cause of $\mathrm{CHI}$. The other recessive form of $\mathrm{CHI}$ is due to mutations in HADH (encoding for-3-hydroxyacyl-coenzyme A dehydrogenase). Dominant forms of $\mathrm{CHI}$ are due to inactivating mutations in $A B C C 8$ and $K C N J 11$, and activating mutations in GLUD1 (encoding glutamate dehydrogenase) and GCK (encoding glucokinase). Recently dominant mutations in HNF4A (encoding hepatocyte nuclear factor $4 \alpha$ ) and SLC16A1 (encoding monocarboxylate transporter 1) have been described which lead to HH. Mutations in all these genes account for about $50 \%$ of the known causes of $\mathrm{CHI}$. Histologically there are three (possibly others which have not been characterised yet) major subtypes of $\mathrm{CHI}$ : diffuse, focal and atypical forms. The diffuse form is inherited in an autosomal recessive (or dominant manner), the focal form being sporadic in inheritance. The diffuse form of the disease may require a near total pancreatectomy whereas the focal form requires a limited pancreatectomy potentially curing the patient. Understanding the genetic basis of $\mathrm{CHI}$ has not only provided novel insights into $\beta$-cell physiology but also aided in patient management and genetic counselling.

Congenital hyperinsulinism (CHI) is biochemically characterised by the dysregulated secretion of insulin from pancreatic $\beta$-cells. It is a major cause of hypoglycaemia in the newborn and infancy period. ${ }^{1}$ The unregulated insulin secretion drives glucose into insulin sensitive tissues (skeletal muscle, liver and adipose tissue) and prevents the generation of alternative energy substrates (such as ketone bodies), thus depriving the brain of both its primary and secondary energy sources. ${ }^{2}$ This prevailing metabolic milieu is the main factor leading to hypoglycaemic brain injury and mental retardation in this group of patients.

The incidence of CHI can vary from 1 in 40000 50000 in the general population to 1 in 2500 in some isolated communities with high rates of consanguinity. ${ }^{3-5}$ It is a heterogeneous condition with regards to the clinical presentation, the underlying genetic aetiology, molecular mechanisms and histological basis of the disease. ${ }^{6-9}$ The clinical presentation can be heterogeneous ranging from completely asymptomatic, mild medically responsive to severe medically unresponsive disease which may require a near total pancreatectomy. Those patients undergoing a total pancreatectomy have a high risk of developing post-pancreatectomy diabetes mellitus and pancreatic exocrine insufficiency.

Insulin secretion from $\beta$-cells is precisely regulated to maintain blood glucose values within the normal range $(3.5-5.5 \mathrm{mmol} / \mathrm{l})$. The genetic basis of $\mathrm{CHI}$ involves defects in key genes which regulate insulin secretion from $\beta$-cells. The most common cause of $\mathrm{CHI}$ are recessive inactivating mutations in ABCC8 and KCNJ11 which encode the two subunits of the adenosine triphosphate sensitive potassium channels (ATP sensitive $\mathrm{K}_{\mathrm{ATP}}$ channels) in the pancreatic $\beta$-cell. ${ }^{10-17}$ These $\beta$-cell $\mathrm{K}_{\mathrm{ATP}}$ channels play a key role in transducing signals derived from glucose metabolism to $\beta$-cell membrane depolarisation and regulated insulin secretion. ${ }^{18}$ The other rare recessive form of $\mathrm{CHI}$ is due to mutations in $H A D H$ (encoding for-3-hydroxyacyl-coenzyme A dehydrogenase). ${ }^{19-21}$ Dominant forms of $\mathrm{CHI}$ are due to inactivating mutations in ABCC8 and KCNJ11 $11^{22-25}$ and activating mutations in GLUD1 (encoding glutamate dehydrogenase), ${ }^{26-31}$ GCK (encoding glucokinase), ${ }^{32-38}$ HNF4A (encoding hepatocyte nuclear factor $4 \alpha$ ) $^{39-41}$ and SLC16A1 (encoding monocarboxylate transporter 1). ${ }^{42}$ Mutations in all these genes account for about $50 \%$ of the known causes of $\mathrm{CHI}$, and in some populations mutations in these genes account for only about $20 \%$ of CHI cases, ${ }^{59434}$ suggesting other novel genetic aetiologies.

Histologically there are three major subgroups of the disease: diffuse, focal, and atypical. ${ }^{45}{ }^{46}$ The diffuse forms of $\mathrm{CHI}$ are inherited in an autosomal recessive or dominant manner and the focal form is sporadic in inheritance. The diffuse form of the disease may require a near total pancreatectomy (with a high risk of developing diabetes mellitus) whereas the focal form requires a limited pancreatectomy offering a complete "cure" for the patient. In patients with atypical disease the histological abnormalities are either more extensive while remaining limited, or diffuse with the coexistence of normal and abnormal islets. ${ }^{46}$

Understanding the genetic basis of $\mathrm{CHI}$ has not only provided novel insights into $\beta$-cell physiology but also aided in patient management and genetic counselling. In terms of patient management rapid genetic analysis for mutations in ABCC 8 and KCNJ11 can help in the genetic diagnosis of diffuse or focal CHI. ${ }^{47}$ Prenatal diagnosis of CHI based on the genetic analysis of known family members with mutations in $A B C C 8$ (and KCNJ11) is also now possible permitting immediate medical management at the time of birth. ${ }^{48}$ This state of the art review will firstly give a brief overview of the role 
Table 1 The genes implicated in congenital hyperinsulinism with the gene loci, proteins affected and patterns of inheritance

\begin{tabular}{|c|c|c|c|c|}
\hline Gene (locus) & OMIM & Protein & Mechanism & Inheritance \\
\hline $\begin{array}{l}\text { ABCC8 } \\
(11 \mathrm{p} 15.1)\end{array}$ & 600509 & Sulfonylurea receptor1 (SUR1) & $\begin{array}{l}\text { Defects in } \mathrm{K}_{\text {ATP }} \text { biogenesis and turnover, trafficking and } \\
\text { nucleotide regulation }\end{array}$ & $\mathrm{AR} / \mathrm{AD}$ \\
\hline $\begin{array}{l}\text { KCNJ11 } \\
(11 \mathrm{p} 15.1)\end{array}$ & 600937 & Inward rectifying potassium channel (Kir6.2) & $\begin{array}{l}\text { Defects in } \mathrm{K}_{\text {ATP }} \text { biogenesis and turnover, trafficking and } \\
\text { nucleotide regulation }\end{array}$ & $\mathrm{AR} / \mathrm{AD}$ \\
\hline & 138130 & Glutamate dehydrogenase (GDH) & $\begin{array}{l}\text { Loss of inhibition of GDH by GTP and increased basal GDH } \\
\text { activity }\end{array}$ & $A D$ \\
\hline $\begin{array}{l}\text { GCK } \\
\text { (7p15-13) }\end{array}$ & 138079 & Glucokinase & Increased affinity of GCK for glucose & $A D$ \\
\hline $\begin{array}{l}\text { SLC16A1 } \\
(1 \mathrm{p} 13.2-\mathrm{p} 12)\end{array}$ & 600682 & Monocarboxylate transporter 1 (MCT1) & Increased expression of MCT1 & $A D$ \\
\hline $\begin{array}{l}\text { HNF4A } \\
(20 q 12-13.1)\end{array}$ & 600281 & Hepatocyte nuclear factor 4 alpha & Unknown & $A D$ \\
\hline
\end{tabular}

$A D$, autosomal dominant; $A R$, autosomal recessive.

of $\beta$-cell $\mathrm{K}_{\mathrm{ATP}}$ channels in regulating insulin secretion, and then focus in detail on the genetic and molecular basis of CHI due to mutations in the known genes and highlight some of the more recent genetic advances. Table 1 summarises the known genetic causes of CHI.

\section{THE ROLE OF $\mathrm{K}_{\text {ATP }}$ CHANNELS IN REGULATING GLUCOSE INDUCED INSULIN SECRETION}

$\mathrm{K}_{\text {ATP }}$ channels have a key role in the physiology of many cells, and defects either in the channel itself or in its regulation can lead to diseases in humans. ${ }^{49} 50$ Functionally $\mathrm{K}_{\text {ATP }}$ channels provide a means of linking the electrical activity of a cell to its metabolic state by sensing changes in the concentration of intracellular nucleotides, and in some cases they mediate the actions of hormones and transmitters. ${ }^{51}$ The pancreatic $\mathrm{K}_{\mathrm{ATP}}$ channel is a functional complex of the sulfonylurea receptor 1 (SUR1) and an inward rectifier potassium channel subunit (Kir6.2) and plays a pivotal role in regulating insulin secretion from the $\beta$-cell. ${ }^{52}$ The Kir6.2 forms the pore of the channel and the SUR1 (an ATP binding cassette transporter) acts as a regulatory subunit.

$\mathrm{K}_{\text {ATP }}$ channels are regulated by adenine nucleotides to convert changes in cellular metabolic levels into membrane excitability. Each subunit of the $\mathrm{K}_{\mathrm{ATP}}$ channel is known to be differentially regulated. The Kir6.2 subunit determines the biophysical properties of the channel complex including $\mathrm{K}^{+}$selectivity, rectification, inhibition by ATP and activation by acyl-CoAs. ${ }^{53}$ The sulfonylurea receptors endow $\mathrm{K}_{\mathrm{ATP}}$ channels with sensitivity to the stimulatory actions of $\mathrm{Mg}$-nucleotides and $\mathrm{K}_{\mathrm{ATP}}$ channel openers (for example, diazoxide, nicorandil) and the inhibitory effects of sulfonylureas and glinides ${ }^{54}$ and endosulfins. ${ }^{55}$

The molecular topology of SUR1 consists of three transmembrane domains, TMD0, TMD1, andTMD2, each of which consists of five, five, and six membrane spanning regions, respectively. ${ }^{56}$ SUR1 also has two nucleotide binding folds (NBF-1 and NBF-2) on the cytoplasmic side with which it senses changes in intracellular $[\mathrm{ATP}] /[\mathrm{ADP}]$ and transmits the signal to the pore. NBF1 appears to be the principal site for ATP binding, whereas NBF2 binds MgADP. ${ }^{56} \mathrm{NBF}-1$ and NBF-2 are located in the loop between TMD1 and TMD2 and in the C-terminus, respectively. These binding domains cooperate with each other in mediating the nucleotide regulation of the pore function. ${ }^{57} \mathrm{NBF}$ of SUR contain highly conserved motifs among $\mathrm{ABC}$ proteins: Walker A motif, Walker $B$ motif, $A B C$ signature motif (also called linker sequence or LSGGQ motif), and an invariant glutamine and histidine residue (also called the Q-loop and H-loop, respectively). Walker A and Walker B motifs are directly involved in nucleotide binding. ${ }^{58}$

$\mathrm{K}_{\mathrm{ATP}}$ channels can only function if they are assembled and correctly transported to the cell membrane surface (trafficking). The assembly and trafficking of $\mathrm{K}_{\mathrm{ATP}}$ channels are intricately linked processes. Only octameric $\mathrm{K}_{\mathrm{ATP}}$ channel complexes are capable of expressing on the cell membrane surface. For example both Kir6.2 and SUR1 possess an endoplasmic reticulum (ER) retention signal (RKR) that prevents the trafficking of each subunit to the plasma membrane in the absence of the other subunit. ${ }^{59}$ Correct assembly of the two subunits masks these retention signals, allowing them to traffic to the plasma membrane. The retention signal is present in the C-terminal region of Kir6.2 and in an intracellular loop between TM11 and NBF-1 in SUR1. Truncation of the C-terminus of Kir6.2 deletes its retention signal, allowing functional expression of Kir6.2 in the absence of SUR1 subunit. ${ }^{60}$ In addition to these retrograde signals, the C-terminus of SUR1 has an anterograde signal, composed in part of a dileucine motif and downstream phenylalanine, which is required for $\mathrm{K}_{\mathrm{ATP}}$ channels to exit the ER/cis-Golgi compartments and transit to the cell surface. ${ }^{61}$ Deletion of as few as seven amino acids, including the phenylalanine, from SUR1 markedly reduces surface expression of $\mathrm{K}_{\text {ATP }}$ channels. ${ }^{62}$ Thus, one function of SUR is as a chaperone protein, to facilitate the surface expression of Kir6.2. There is also some evidence that Kir6.2 provides a reciprocal service for SUR. ${ }^{63}$

The SUR1 protein shows a high affinity binding capacity to the sulfonylurea glibenclamide, indicating that SUR1 confers sulfonylurea binding. ${ }^{64}{ }^{65}$ The sulfonylurea drugs (glibenclamide and tolbutamide) inhibit the channels and are used in the treatment of non-insulin dependent (type II) diabetes mellitus. The other class of drugs, known as potassium channel openers (for example, diazoxide), activate the channel and are used to suppress insulin secretion. ${ }^{65}$

\section{GENETIC BASIS OF CHI DUE TO RECESSIVE INACTIVATING MUTATIONS IN ABCC8 AND KCNJ11}

The ABCC 8 gene consists of 39 exons and spans more than $100 \mathrm{~kb}$ of genomic DNA. ${ }^{66}$ The human SUR1 cDNA contains a single open reading frame that encodes for 1582 amino acids with a molecular weight of 177 kDa (GenBank NM_000352.2). Kir6.2 consists of a single exon encoding for a protein of 390 amino acids (GenBank NM 000525.2).52 The ABCC8 and KCNJ11 genes are both located on chromosome 11p15.1, separated by only a small stretch of $4.5 \mathrm{~kb}$ of DNA. ${ }^{66}$ 


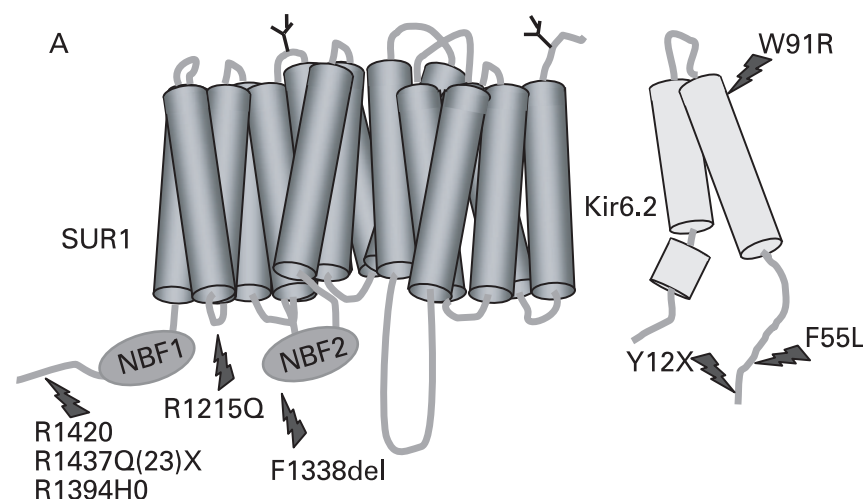

$\mathrm{R} 1394 \mathrm{HO}$

B

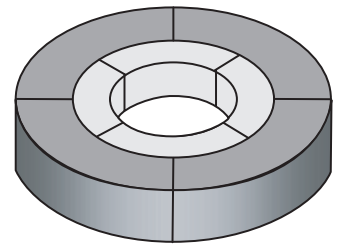

Figure 1 (A) Schematic outline of the components of the $\beta$-cell $K_{\text {ATP }}$ channel. The $K_{\text {ATP }}$ channel is composed of two proteins: SUR1 which consists of 17 transmembrane domains with two intracellular nucleotide binding (NBF) motifs. Two N-linked glycosylation sites are present on amino acids 10 and 1049. Kir6.2 has three transmembrane segments. Common mutations in both of the proteins are highlighted. (B) The hetero-octameric arrangement of the $\mathrm{K}_{\text {ATP }}$ channel.

Homozygous, compound heterozygous and heterozygous recessive inactivating mutations (missense, frameshift, nonsense, insertions/deletions (macrodeletion), splice site and regulatory mutations) have been reported in ABCC8 and KCNJ11. ${ }^{10-17} 6768$ So far, more than 150 mutations have been reported in $A B C C 8$ and 25 in KCNJ11. ${ }^{69}$ In the Ashkenazi Jewish population two common mutations (F1388del and c.3992-9G4A) account for $90 \%$ of all cases of $\mathrm{CHI}^{9}{ }^{10}$ whereas in the Finnish population, two founder mutations have been reported (V187D and E1507 K). ${ }^{14} 22$ Recessive inactivating mutations in ABCC 8 and KCNJ11 usually cause severe $\mathrm{CHI}$ which in the vast majority of patients is unresponsive to medical treatment with diazoxide. However, some compound heterozygote mutations may be milder and may respond to treatment with diazoxide. ${ }^{70}$ Compound heterozygote mutations may result in complex interactions resulting in intracellular retention of channel complexes. ${ }^{71}$ The molecular basis of recessive inactivating ABCC8 and KCNJ11 mutations involves multiple defects in $\mathrm{K}_{\text {ATP }}$ channel biogenesis and turnover, in channel trafficking from the ER and Golgi apparatus to the plasma membrane and alterations of channels in response to both nucleotide regulation and open state frequency. Figure 1 shows a schematic outline of the $\beta$-cell $K_{\text {ATP }}$ channel and locations of the some of the common mutations.

\section{Recessive ABCC8 and KCNJ11 mutations resulting in defects in channel biogenesis and turnover}

The mechanisms that control the maturation and assembly of $\mathrm{K}_{\text {ATP }}$ channels are not well understood. Pulse labelling studies have shown that when Kir6.2 is expressed individually, its turnover is biphasic with about $60 \%$ being lost with a half life of 36 min. $^{72}$ The remainder converts to a long lived species (half life $26 \mathrm{~h}$ ) with an estimated half time of $1.2 \mathrm{~h}$. Expressed alone SUR1 has a long half life of $25.5 \mathrm{~h}$. When Kir6.2 and SUR1 are co-expressed, they associate rapidly and the fast degradation of
Kir6.2 is eliminated. ${ }^{72}$ Two mutations, KCNJ11 (W91R) and $A B C C 8$ (F1388del), identified in patients with the severe form of CHI, profoundly alter the rate of Kir6.2 and SUR1 turnover, respectively. ${ }^{72}$ Both mutant subunits associate with their respective partners but dissociate freely and degrade rapidly, suggesting that the mutations alter channel biogenesis and turnover.

\section{Recessive inactivating mutations in ABCC8 and KCNJ11 resulting in defects in channel trafficking}

Trafficking of $\mathrm{K}_{\mathrm{ATP}}$ channels requires that the ER retention signal, RKR, present in both SUR1 and Kir6.2, is shielded during channel assembly. Some mutations in ABCC8 (such as R1437Q(23)X, F1388del and R1394H0) cause a trafficking defect by affecting the exit of channel subunits from the ER compartment. ${ }^{13}{ }^{73-75}$ The $\mathrm{R} 1437 \mathrm{Q}(23) \mathrm{X}$, mutation in exon 35 of ABCC8 truncates 200 amino acids from the $\mathrm{COOH}$ terminal region of the protein, an area that contains the anterograde signalling sequence (L1566, L1567.F1574) and residue L1544 which is part of the cloaking region for the RKR sequence. ${ }^{76}$ This defect affects the exit of channel subunits from the ER.

The pivotal role played by the RKR signal in allowing the channels to express correctly on the $\beta$-cell membrane is illustrated by the fact that when the RKR signal is inactivated by an in-frame deletion (F1388del SUR1 $1_{\mathrm{AAA}}$ ), channel activity is impaired, but when surface expression is rescued, the channels function normally. ${ }^{73}$ Other mutations such as the $\mathrm{R} 1394 \mathrm{H}$ $(A B C C 8)$ cause a trafficking disorder by effecting retention of mutant proteins in the trans-Golgi network. ${ }^{74}$

Mutations in KCNJ11 can also cause defective trafficking and truncated non-functional proteins. For example, the Kir6.2 mutation (Y12X) causes the synthesis of a truncated nonfunctional protein ${ }^{12}$ whereas another mutation (W91R) leads to defective channel assembly with a rapid degradation in the ER. ${ }^{72}$ Recently, a new homozygous mutation H259R (KCNJ11) has been shown to lead to a non-functional $K_{\text {ATP }}$ channels with impaired trafficking to the cell membrane. ${ }^{16}$

\section{Recessive inactivating mutations in ABCC8 and KCNJ11 resulting in defects of channel regulation}

The SUR1 subunit plays a key role in determining the pharmacological regulation of $\mathrm{K}_{\mathrm{ATP}}$ channels with SUR1 acting as a conductance regulator of Kir6.2. The sensitivity of $\mathrm{K}_{\text {ATP }}$ channels to changes in ATP, ADP, and guanosine (GTP, GDP) nucleotides involves both subunits. The functional regulation of $\mathrm{K}_{\mathrm{ATP}}$ channels is induced by changes in the ATP/ADP ratio. This involves cooperative interactions of nucleotides at both subunits with the actions of ATP induced inhibition of Kir6.2 being countered by the activation of ADP at SUR1. Hence, mutations that affect the regulation of the $\mathrm{K}_{\mathrm{ATP}}$ channels by altering its sensitivity to changes in ADP/ATP will lead to unregulated insulin secretion. Several mutations in ABCC8 (for example, R1420C, T1139M and R1215O) have now been described that result in the loss of $\mathrm{ADP}$ dependent gating properties of the channel. $^{757778}$ Loss of ADP dependent gating results in the constitutive inhibition of $\mathrm{K}_{\mathrm{ATP}}$ channels by ATP.

\section{Dominant inactivating $A B C C 8$ and $K C N J 11$ mutations causing CHI}

Dominant inactivating mutations in $A B C C 8$ and KCNJ11 have been described which lead to $\mathrm{CHI} \cdot{ }^{22-25}$ However, the phenotype of patients with dominant inactivating mutations in $A B C C 8$ and KCNJ11 seems to be much milder than that of patients 
with recessive inactivating $A B C C 8$ and KCNJ11 mutations. Patients with dominant mutations seem to be responsive to medical treatment with diazoxide, may present later than those with recessive mutations, and do not require a pancreatectomy. ${ }^{24}$ In one large study of 16 families with dominant CHI caused by mutations in $A B C C 8$ or KCNJ11, all of the mutations were conservative single amino acid changes, allowing for normal channel formation at the plasma membrane. ${ }^{24}$ Whereas recessive mutations cause near absence of $\mathrm{K}_{\text {ATP }}$ channel activity (to have defects in channel biogenesis or trafficking of mature functional channels to the plasma membrane), dominant mutations demonstrate normal channel assembly with their respective wild type partner and normal trafficking of assembled channels to the plasma membrane when expressed in vitro.

A dominant missense CHI causing mutation F55L (KCNJ11) has been shown to greatly reduce the open probability of $\mathrm{K}_{\mathrm{ATP}}$ channels in intact cells without affecting channel expression. ${ }^{25}$ It was shown that the low channel activity was due to reduced channel response to membrane phosphoinositides and/or long chain acyl-CoAs, as application of exogenous $\mathrm{PIP}_{2}$ or oleoyl-CoA restored channel activity similar to that seen in wild type channels. These electrophysiological observations provide a link between $\mathrm{K}_{\mathrm{ATP}}$ channels and their regulation by membrane phosphoinositides and/or long-chain acyl-CoAs. ${ }^{79}$

\section{DOMINANT ACTIVATING MUTATIONS IN GLUD1}

The GLUD1 gene is located on chromosome 10q23.3 and contains 13 exons coding for a 505 amino acid mature enzyme, glutamate dehydrogenase $(\mathrm{GDH}) \cdot{ }^{80} \mathrm{GDH}$ is a mitochondrial matrix enzyme which is expressed at high levels in the liver, brain, kidney, pancreas, heart and lungs. ${ }^{81}$ This enzyme catalyses the oxidative deamination of glutamate to $\alpha$-ketoglutarate and ammonia using $\mathrm{NAD}^{+}$and/or $\mathrm{NADP}^{+}$as co-factors. In the $\beta$-cell $\alpha$-ketoglutarate enters the tricarboxylic acid cycle and leads to an increase in the cellular ATP. This increases the ATP/ADP ratio which triggers closure of the $\mathrm{K}_{\mathrm{ATP}}$ channels and depolarisation of the $\beta$-cell membrane. This, in turn, opens the voltage gated calcium channel, raises the cytosolic calcium, and triggers the release of insulin. GDH plays a critical step in glutaminolysis and regulating amino acid induced insulin secretion. ${ }^{82}$ Its activity is regulated by a complex interplay of allosteric activators and inhibitors. Positive allosteric effectors of $\mathrm{GDH}$ include leucine, and ADP (adenine diphosphate), whereas GTP (guanosine $5^{\prime}$-triphosphate) is a potent allosteric inhibitor. ${ }^{83}$ Allosteric activation of glutaminolysis is one mechanism by which the amino acid leucine stimulates insulin secretion. ${ }^{83}$
Activating mutations (heterozygous missense single amino acid substitutions) in the GLUD1 gene are the second most common cause of CHI. GLUD1 gene mutations cause a form of $\mathrm{CHI}$ in which affected children have recurrent symptomatic $\mathrm{HH}$ together with a persistently elevated plasma ammonia value, the hyperinsulinism/hyperammonaemia (HI/HA) syndrome. ${ }^{26} 84-86$ The mutations causing HI/HA reduce the sensitivity of the enzyme to allosteric inhibition by the high energy phosphate GTP $^{27} 86$ and in rare cases increase basal GDH activity. ${ }^{28} 297$ The loss of inhibition by GTP increases the rate of oxidation of glutamate in the presence of leucine, thereby increasing insulin secretion. The clinical picture is hence characterised by postprandial hypoglycaemia following a protein meal (fasting hypoglycaemia may also occur). The mechanism of persistent hyperammonaemia, ${ }^{86} 8 \mathrm{a}$ striking and consistent feature of this condition, is not completely understood. The hypoglycaemia in patients with HI/HA syndrome is usually responsive to medical treatment with diazoxide. The hyperammonaemia is considered to be asymptomatic and hence efforts to reduce plasma ammonia values with sodium benzoate or $N$-carbamylglutamate do not seem to be beneficial.

Glutamate dehydrogenase is a homohexameric enzyme with two trimeric subunits; each subunit is composed of at least three domains. Mutations in GLUD1 occur most commonly in the GTP allosteric binding domain of GDH (exons 11 and 12). ${ }^{26}{ }^{27}$ Mutations in the catalytic domain (exons 6 and 7) have also been identified. ${ }^{29}$ This domain interacts with GTP molecules and mutations in the allosteric and catalytic domains have been shown to cause hyperinsulinism by diminishing the sensitivity of GDH to GTP. The third domain is an antenna-like structure connecting to the pivot helix where mutations (exon 10) have also been reported. ${ }^{28}{ }^{31}$ Functional analysis of these mutations has shown that they are associated with a higher basal GDH activity and a milder insensitivity to GTP inhibition in comparison with mutations in the other two domains. ${ }^{28} 31$ Most cases of HI/HA syndrome occur sporadically; however, families with HI/HA syndrome where the mutation has been dominantly inherited have also been described. ${ }^{30}$ Figure 2 summarises the mutations in the GLUD1 gene known to cause CHI.

\section{DOMINANT ACTIVATING MUTATIONS IN GCK}

The glucokinase gene (GCK) is located on chromosome 7p15.3p15.1 and comprises 12 exons which span $\sim 45,168$ bp and encode for a 465 amino acid protein with a molecular weight of $52191 \mathrm{Da}$. The gene is transcribed in various tissues but it has tissue specific promoters and is especially expressed in the
Figure 2 Schematic representation of the mutations in the GLUD1 gene known to cause congenital hyperinsulinism. Mutations are described to occur in three domains: the allosteric binding domain (exons 11 and 12), the catalytic domain (exons 6 and 7), and the antenna region (exon 10).

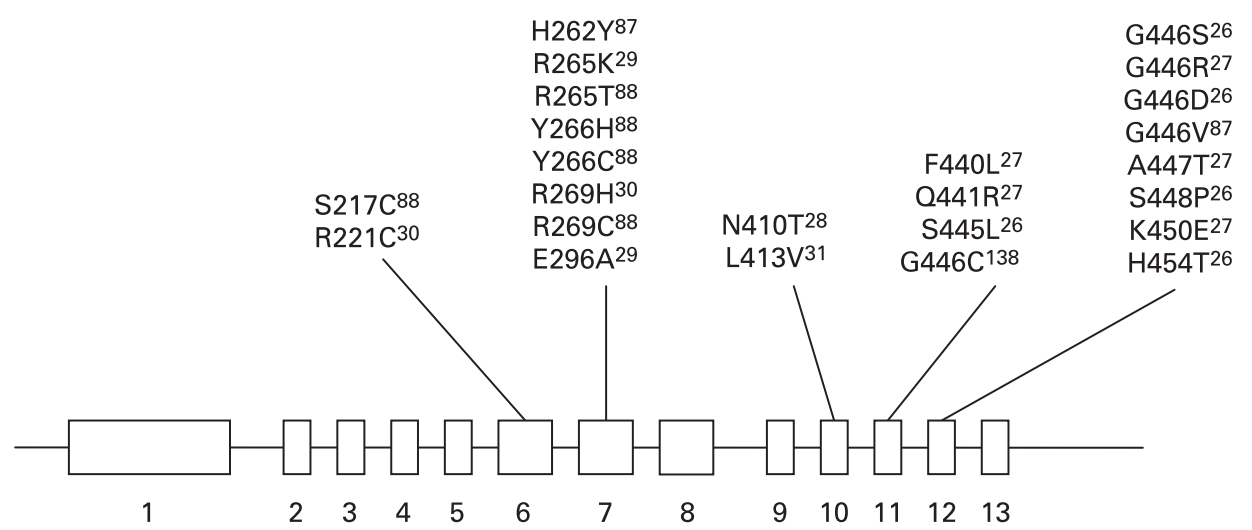

R265K 29

$\mathrm{R} 265 \mathrm{~T}^{88}$

$\mathrm{R} 269 \mathrm{H}^{30}$

$\mathrm{R} 269 \mathrm{C}^{88}$

$96 A^{29}$ 
pancreas, liver, and brain. ${ }^{89}$ The presence of tissue specific promoters allows differential regulation and transcription of different transcripts giving rise to three different sized versions of exon $1(a, b$, and $c)$. In the pancreas the upstream promoter is functional, while in the liver the downstream promoter is used. $^{89}$ Exon $1 \mathrm{a}$ is expressed in the pancreatic $\beta$-cells whereas exons $1 \mathrm{~b}$ and $1 \mathrm{c}$ are expressed in the liver. ${ }^{89}$

Glucokinase (hexokinase IV or D) is one member of the hexokinase family of enzymes. The name, glucokinase, is derived from its relative specificity for glucose under physiologic conditions. Glucokinase is a key regulatory enzyme in the pancreatic $\beta$-cells. It operates as a monomer and phosphorylates glucose on carbon 6 with MgATP as a second substrate to form glucose-6-phosphate (G6P) as a first step in the glycolytic pathway. It plays a crucial role in the regulation of insulin secretion and has been termed the pancreatic $\beta$-cell sensor on account of its kinetics, because the rate of phosphorylation of glucose in the pancreatic $\beta$-cells is directly related to the concentration of glucose over a range of physiological glucose concentrations (4-15 mmol/l).$^{90}$ These kinetic characteristics are the enzyme's low affinity for glucose (concentration of glucose at which the enzyme is half maximally activated, S0.5, 8-10 mmol/l), cooperativeness with glucose (Hill number of 1.7), and lack of inhibition by its product G6P..$^{90}$ The enzyme has at least two clefts, one for the active site, binding glucose and MgATP, and the other for a putative allosteric activator. Glucokinase activity is closely linked to the $\mathrm{K}_{\mathrm{ATP}}$ and calcium channels of the $\beta$-cell membrane, resulting in a threshold for glucose stimulated insulin release of approximately $5 \mathrm{mmol} / \mathrm{l}$, which is the set point of glucose homoeostasis. ${ }^{91}$

Heterozygous inactivating mutations in GCK cause maturity onset diabetes of the young (MODY), homozygous inactivating in GCK mutations result in permanent neonatal diabetes, whereas heterozygous activating GCK mutations cause CHI. So far seven activating GCK mutations (V455M, A456V, Y214C, T65I, W99R, G68V, S64Y) have been described that lead to CHI (fig 3). ${ }^{32-38}$ Activating GCK mutations increase the affinity of GCK for glucose and alter (reset) the threshold for glucose stimulated insulin secretion. All reported activating mutations cluster in a region of the enzyme, which has been termed the allosteric activator site and is remote to the substrate binding site. The allosteric site of GCK is where small molecule activators bind, suggesting a critical role of the allosteric site in the regulation of GCK activity. ${ }^{92}$ Both GCK activators and activating mutations increase enzyme activity by enhancing the affinity for glucose as described by a decrease in K0.5. ${ }^{93}$ There is no evidence to suggest that over-expression of GCK (increased gene dosage effect) is a likely cause of $\mathrm{CHI} .{ }^{94}$

The clinical symptoms and course of patients with GCK mutations cover a broad spectrum from asymptomatic hypoglycaemia to unconsciousness and seizures, even within the same family with the same mutation, implicating a complex mechanism for GCK regulation. Patients with activating GCK mutations may present with postprandial hyperinsulinaemic hypoglycaemia. ${ }^{95}$ Most of the GCK mutations reported to date cause mild diazoxide responsive CHI. However, a "de novo" mutation in GCK (Y214C) was described in a patient with medically unresponsive $\mathrm{CHI} .{ }^{35}$ This mutation was located in the putative allosteric activator domain of the protein and functional studies of purified recombinant glutathionyl $\mathrm{S}$ transferase fusion protein of GK-Y214C showed a sixfold increase in its affinity for glucose, a lowered cooperativity, and increased kcat. ${ }^{35}$ The relative activity index of GKY214C was 130, and the threshold for glucose stimulated insulin secretion was predicted by mathematical modelling to be $0.8 \mathrm{mmol} / \mathrm{l}$, as compared with $5 \mathrm{mmol} / \mathrm{l}$ in the wild-type enzyme. ${ }^{35}$ In the largest study performed to date on a pool of patients who were negative for mutations in the ABCC8 and KCNJ11 genes, the prevalence of CHI due to mutations in GCK was estimated to be about $7 \%{ }^{38}$

\section{RECESSIVE MUTATIONS IN HADH}

Mitochondrial fatty acid $\beta$-oxidation constitutes the essential physiological response to energy depletion caused by fasting, severe febrile illness or increased muscular activity. The process of $\beta$-oxidation results in production of acetyl-CoA by the sequential oxidation and cleavage of straight chain fatty acids. Importantly, hepatic $\beta$-oxidation provides the source of energy for extrahepatic tissues through ketone body formation upon fasting. HADH encodes for the enzyme L-3-hydroxyacylcoenzyme A dehydrogenase $(\mathrm{HADH})$ (previously known as short-chain L-3-hydroxyacyl-CoA dehydrogenase (SCHAD)), which is an intra-mitochondrial enzyme that catalyses the penultimate step in the $\beta$-oxidation of fatty acids, the $\mathrm{NAD}^{+}$ dependent dehydrogenation of 3-hydroxyacyl-CoA to the corresponding 3-ketoacyl-CoA. Human HADH encodes a 314 amino acid protein with eight exons and spans approximately $49 \mathrm{~kb} .{ }^{96}$ It is composed of a 12 residue mitochondrial import signal peptide and a 302 residue mature $\mathrm{HADH}$ protein with a calculated molecular mass of $34.3 \mathrm{kD} .{ }^{97}$

Loss-of-function mutations in the $H A D H$ gene are associated with CHI. ${ }^{19-21}$ The clinical presentation of all patients reported is heterogeneous, with either mild late onset intermittent $\mathrm{HH}$ or severe neonatal hypoglycaemia. All reported cases have presented with increased 3-hydroxyglutarate in urine and hydroxybutyrylcarnitine in blood which may be diagnostically useful markers for $\mathrm{HADH}$ deficiency. In the first patient reported sequencing of the HADH genomic DNA from the fibroblasts showed a homozygous mutation (C773T) changing proline to leucine at amino acid 258. ${ }^{19}$ Analysis of blood from the parents showed they were heterozygous for this mutation. Western blot studies showed undetectable levels of immunoreactive $\mathrm{HADH}$ protein in the patient's fibroblasts. Expression studies showed
Figure 3 Schematic representation of the mutations in the GCK gene known to cause congenital hyperinsulinism.

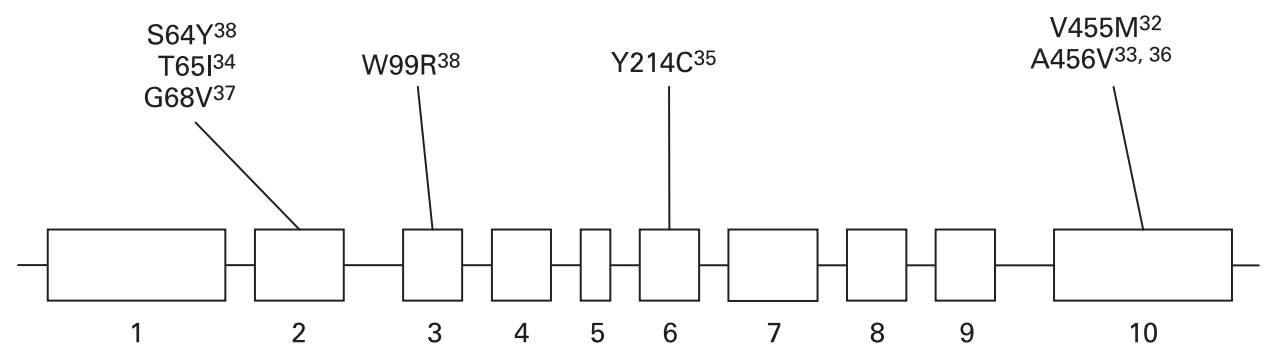


that the P258L enzyme had no catalytic activity. This patient presented with intermittent hypoglycaemia at 4 months of age.

A novel, homozygous deletion mutation (deletion of the six base pairs CAGGTC at the start of $H A D H$ exon 5) was found in the second patient who presented with severe neonatal hypoglycaemia. ${ }^{21}$ The mutation affected RNA splicing and was predicted to lead to a protein lacking 30 amino acids. The observations at the molecular level were confirmed by demonstrating greatly reduced $\mathrm{HADH}$ activity in the patients' fibroblasts and enhanced levels of 3-hydroxybutyryl-carnitine in their plasma. Urine metabolite analysis showed that $\mathrm{HADH}$ deficiency resulted in specific excretion of 3-hydroxyglutaric acid. ${ }^{21}$ Finally, the third patient reported to date was found to be homozygous for a splice site mutation (IVS6-2 a/g) in the $H A D H$ gene with western blotting with an anti-HADH antibody indicating a decrease in the amount of immunoreactive protein in fibroblasts from the patient consistent with the observed decrease in enzyme activity. ${ }^{20}$

The molecular mechanism of how loss of function in the $H A D H$ gene leads to unregulated insulin secretion is still unclear. Several recent studies in rodents have begun to give some insight into how $H A D H$ regulates insulin secretion and its interaction with other genes involved in $\beta$-cell development and function. ${ }^{98-101}$ The normal $\beta$-cell phenotype is characterised by a high expression of $H A D H$ and a low expression of other $\beta$-oxidation enzymes. Downregulation of $H A D H$ causes an elevated secretory activity suggesting that this enzyme protects against inappropriately high insulin values and hypoglycaemia. ${ }^{98} 99$ Hence, HADH seems to be a negative regulator of insulin secretion in $\beta$-cells. Further studies will be required to understand fully the biochemical pathways by which defects in $H A D H$ lead to dysregulated insulin secretion.

\section{RECENT ADVANCES IN THE GENETIC AETIOLOGY OF CHI}

A further mechanism of hyperinsulinaemic hypoglycaemia has been described whereby strenuous physical exercise causes an inappropriate burst of insulin release that can lead to hypoglycaemia. ${ }^{102} 103$ This work led to the identification of the molecular basis of exercise induced CHI (due to mutations in SLC16A1). ${ }^{42}$ Mutations in HNF4A have been recently reported to cause both transient and persistent hyperinsulinaemic hypoglycaemia associated with macrosomia and a family history of maturity onset diabetes of the young. ${ }^{39} 41$

\section{DOMINANT MUTATIONS IN SLC16A1 CAUSING EXERCISE INDUCED CHI}

In the glycolytic pathway glucose is metabolised to pyruvate which then enters in the mitochondria. Pyruvate can be converted into lactate or enters into the tricarboxylic acid cycle, generating reducing equivalents. This leads to stimulation of the respiratory chain and ATP synthesis. The transport of monocarboxylates such as lactate and pyruvate is mediated by the SLC16A family of proton linked membrane transport proteins known as monocarboxylate transporters (MCTs). Fourteen MCT related genes have been identified in mammals and of these seven MCTs have been functionally characterised. Despite their sequence homology, only MCT1-4 have been demonstrated to be proton dependent transporters of monocarboxylic acids. ${ }^{104}$

The SLC16A1 gene encodes for MCT1 that mediates the movement of lactate and pyruvate across cell membranes. The SLC16A1 gene maps to chromosome 1p13.2-p12, spans approximately $44 \mathrm{~kb}$, and is organised as five exons intervened by four introns. ${ }^{105} 106$ The first of these introns is located in the $5^{\prime}$ UTR encoding DNA, spans $>26 \mathrm{~kb}$, and thus accounts for approximately $60 \%$ of the entire transcription unit. ${ }^{106}$ Analysis of a $1.5 \mathrm{~kb}$ fragment of the MCT1 5' flanking region shows an absence of the classical TATA-Box motif. However, the region contains potential binding sites for a variety of transcription factors. ${ }^{105}$

Studies in whole rat and mouse islets have shown that pyruvate and lactate cannot mimic the effect of glucose on insulin secretion despite active metabolism. ${ }^{107} 108$ This is postulated to be due to low expression of MCT in $\beta$-cells. However, over expression of lactate dehydrogenase (LDH) and MCT1 leads to pyruvate induced insulin secretion. ${ }^{108}$ In exercise induced CHI there is increased expression of MCT1 transporter in $\beta$-cells due to dominant mutations in SLC16A1. ${ }^{42}$ In these patients anaerobic physical exercise induces $\mathrm{HH}$ that is preceded by an inappropriate increase in the concentration of circulating insulin. ${ }^{102} 103$ Affected patients become hypoglycaemic within 30 min after a short period of anaerobic exercise. A pyruvate load test causes a brisk increase in the serum insulin concentration suggesting that pyruvate metabolism or transport is in some way involved in signalling insulin secretion from $\beta$-cells in these patients. ${ }^{109}$ A genome scan performed on two families with 10 affected patients first mapped the gene to chromosome $1 .^{42}$ Mutations in the promoter region of SLC16A1 gene were confirmed in all patients. Studies on cultured fibroblasts from affected patients showed abnormally high SLC16A1 transcript levels, although the MCT1 transport activity was unchanged in fibroblasts (possibly reflecting additional post-transcriptional control of MCT1 levels in extrapancreatic tissues).

Two of the SLC16A1 mutations identified in separate pedigrees resulted in increased protein binding to the corresponding promoter elements and marked (3- or 10-fold) transcriptional stimulation of SLC16A1 promoter-reporter constructs. ${ }^{42}$ Some of the mutations were in the binding sites of several transcription factors (nuclear matrix protein 1, albumin negative factor (ANF) and AML-1a, simian-virus-40-protein-1 (Sp1), upstream stimulatory factor (USF), myeloid zinc finger 1 (MZF1), and GATA-1 binding site). These studies suggest that activating mutations in the promoter region of SLC16A1 could induce increased expression of MCT1 in the $\beta$-cell (where this gene is not usually transcribed) allowing pyruvate uptake and pyruvate stimulated insulin release despite ensuing hypoglycaemia. ${ }^{42}$

\section{DOMINANT HETEROZYGOUS MUTATIONS IN HNF4A}

Hepatocyte nuclear factor $4 \alpha(\mathrm{HNF} 4 \alpha)$ is a transcription factor of the nuclear hormone receptor superfamily and is expressed in liver, kidney, gut, and pancreatic islets. ${ }^{110}$ In combination with other hepatocyte nuclear factors, HNF4 $\alpha$ has been proposed to form a functional regulatory loop that regulates the development and function of the pancreas and the liver. ${ }^{111}{ }^{112}$ In $\beta$-cells, HNF $4 \alpha$ has been shown to be the most widely acting transcription factor and regulates several key genes involved in glucose stimulated insulin secretion. ${ }^{113}{ }^{114}$

The HNF4A gene is located on human chromosome 20q13.113.2. The gene consists of at least 12 exons and spans $30 \mathrm{~kb}$. The HNF4A gene has two promoters, $\mathrm{P} 1$ and $\mathrm{P} 2$, with $\mathrm{P} 2$ being upstream to $\mathrm{P} 1$. The distant upstream $\mathrm{P} 2$ promoter represents the major transcription site in $\beta$-cells, and is also used in hepatic cells. Transfection assays with various deletions and mutants of the P2 promoter revealed functional binding sites for HNF1A, $H N F 1 B$, and IPF1. ${ }^{115}$ The HNF4 $\alpha$ protein consists of an $\mathrm{N}$-terminal ligand independent transactivation domain (amino acids 1-24), a DNA binding domain containing two zinc fingers 
Figure 4 Summary of common mutations in the pancreatic $\beta$-cell leading to congenital hyperinsulinism. (1) The ATP gated potassium channel encoded by ABCC8 and KCNJ11. (2) Glutamate dehydrogenase (GDH) encoded by GLUD1. (3) Glucokinase (GCK), the initial enzyme in the glycolysis pathway. (4) L3-hydroxyacyl-coenzyme A dehydrogenase (HADH), the penultimate enzyme in the $\beta$-oxidation pathway encoded by $H A D H$. (5) Mutations in $H N F 4 \alpha$ cause multiple defects in glucose stimulated insulin secretion. (6) The monocarboxylate transporter MCT1 encoded by SLC16A1. TCA, tricarboxylic acid.

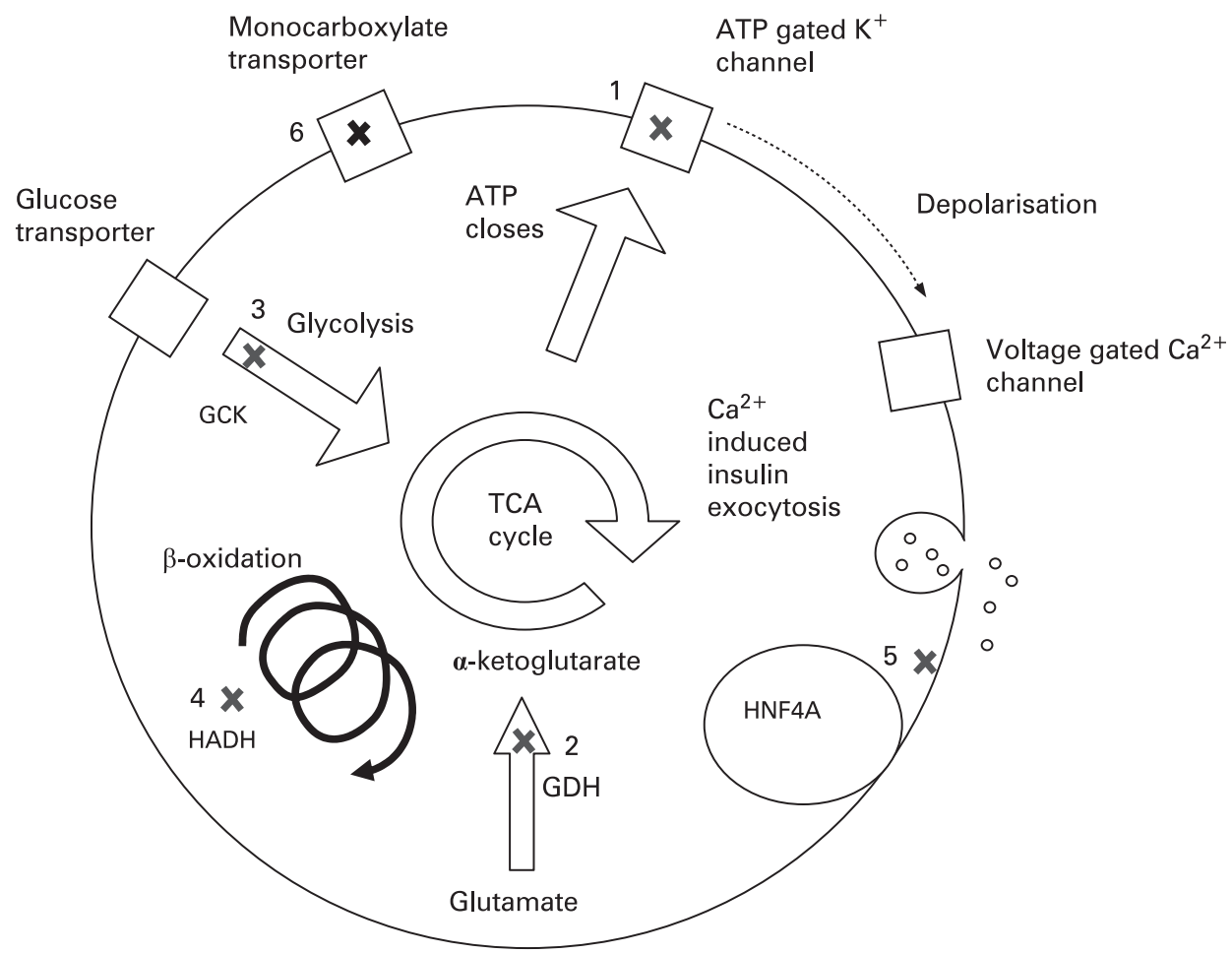

(amino acids 51-117), and a large hydrophobic portion (amino acids 163-368) composed of the dimerisation, ligand binding, co-factor binding, and ligand dependent transactivation domain. ${ }^{116}$

Heterozygote mutations in the human HNF4A gene classically lead to maturity onset diabetes of the young subtype 1 (MODY1), which is characterised by autosomal dominant inheritance and impaired glucose stimulated insulin secretion from pancreatic $\beta$-cells. ${ }^{117}$ These mutations in the HNF4A gene cause multiple defects in glucose stimulated insulin secretion and in expression of HNF4A dependent genes. ${ }^{117}{ }^{118}$ Recently mutations in the HNF4A gene were reported to cause macrosomia and both transient and persistent $\mathrm{HH} \cdot{ }^{39-41}$ In one retrospective study the birth weight of the HNF4A mutation carriers compared to non-mutation family members was increased by a median of $790 \mathrm{~g} .{ }^{39}$ Transient hypoglycaemia was reported in 8/54 infants with heterozygous HNF $4 A$ mutations and documented $\mathrm{HH}$ in three cases. ${ }^{39}$

In another prospective study three infants presented with macrosomia and severe $\mathrm{HH}$ with a positive family history of MODY. ${ }^{41}$ All three patients required diazoxide treatment to maintain normoglycaemia. Sequencing of the HNF4A gene identified heterozygous mutations in all three families. ${ }^{41}$ In family 1, a frameshift mutation L330fsdel17ins9 (c.987 1003del17ins9; p.Leu330fs) was present in the proband; a mutation affecting the conserved A nucleotide of the intron 2 branch site (c.264-21A $>$ G) was identified in the proband of family 2; and finally a nonsense mutation, Y16X (c.48C >G, p.Tyr16X), was found in the proband of family $3 .{ }^{41}$ Hence mutations in the HNF4A gene are a novel cause of both transient and persistent $\mathrm{HH}$.

At present it is unclear how heterozygote mutations in HNF4A lead to hypoglycaemia. Using the conditional Cre-loxPbased inactivation system to delete HNF4A specifically in the pancreatic $\beta$-cell, Gupta et al studied glucose homeostasis in the adult mice. ${ }^{119}$ These mice were hyperinsulinaemic in fasted and fed state but also paradoxically had impaired glucose tolerance with inadequate insulin secretion after glucose stimulation. Cotransfection assays demonstrated that these mice had a $60 \%$ reduction in the expression of the Kir6.2 subunit of the potassium channel. However, two further studies ${ }^{39} 120$ have reported no change in the expression of Kir6.2 in HNF $4 \mathrm{~A}$ deficient mice suggesting that this loss of expression of Kir6.2 in the pancreatic $\beta$-cell may not be the cause of the dysregulated insulin secretion. Hence, it is unclear how heterozygous mutations in the HNF4A gene cause $\mathrm{HH}$ in the newborn period followed by the opposite phenotype of MODY-1 in young adulthood. Figure 4 summarises the genetic causes of $\mathrm{CHI}$.

\section{THE GENETIC BASIS OF FOCAL CHI}

CHI presents as three (probably more, but these have not been fully defined yet) different morphological forms: a diffuse form with functional abnormality of islets throughout the pancreas; an atypical form where the pathophysiology is unclear; and a focal form with focal islet cell adenomatous hyperplasia, which can be cured by partial pancreatectomy. ${ }^{121}$ Focal CHI is characterised by nodular hyperplasia of islet-like cell clusters, including ductuloinsular complexes and giant $\beta$-cell nuclei. ${ }^{122}$ The genetic aetiology of focal CHI is distinct from that of diffuse CHI. Focal adenomatous hyperplasia involves the specific loss of the maternal $11 \mathrm{p} 15$ region and a constitutional mutation of a paternally inherited allele of the genes ABCC8/ KCNJ11 encoding the $\mathrm{K}_{\text {ATP }}$ channel. ${ }^{123-128}$ The specific loss of the maternal $11 \mathrm{p} 15$ region within the focal region results in paternal isodisomy and a paternally inherited mutation in ABCC8/ KCNJ11. ${ }^{124} 129$ The reduction to homozygosity of a paternally inherited $A B C C 8 / K C N J 11$ mutation within the focal lesion leads to uncontrolled secretion of insulin (fig 5).

Deletion mapping experiments have shown that the most commonly deleted region encompasses two regions of interest: the $11 \mathrm{p} 15.5$ region, subject to imprinting, and the $11 \mathrm{p} 15.4$ region containing the $A B C C 8 / K C N J 11$ genes, which are not 
Figure 5 Genetic aetiology of a focal lesion. Panel A shows normal parental chromosomes 11 with the distal region of the short arm containing the $A B C C 8$ and KCNJ11 channel genes, and imprinted genes (H19 and P57 ${ }^{K I P 2}$ and IGF2), that influence cellular proliferation. Panel B explains the genetic basis of a focal lesion that results from paternal inheritance of a recessive $A B C C 8$ or KCNJ11 mutation and the somatic loss of heterozygosity of the distal portion of the short arm of chromosome 11.

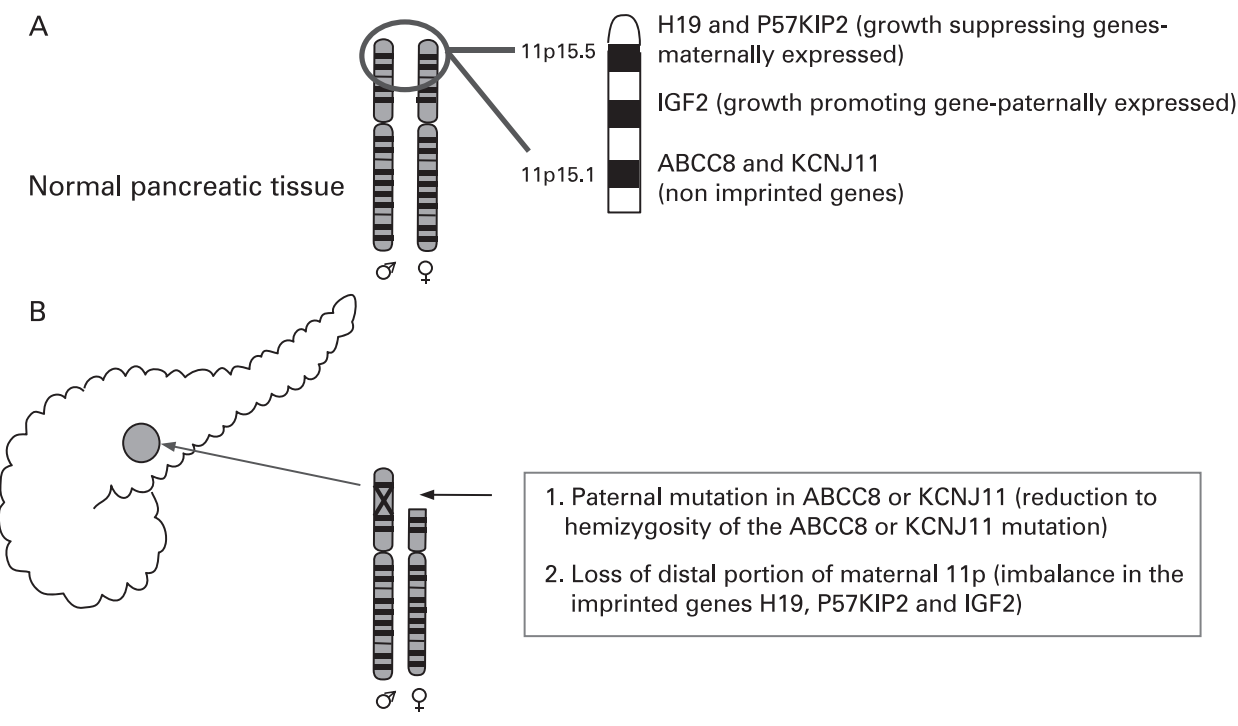

Focal lesion imprinted. ${ }^{123}$ The $11 \mathrm{p} 15.5$ chromosome region involved contains an imprinted domain, including several imprinted genes characterised by mono-allelic expression. ${ }^{130-133}$ These include four maternally expressed genes (H19, a candidate tumour suppressor gene; P57KIP2, a negative regulator of cell proliferation; KVLQT1, the gene coding for the potassium channel involved in the long OT syndrome; HASH2, a transcription factor; and one paternally expressed gene, the insulin-like growth factor 2 (IGF2). ${ }^{128} 132-136$

The imbalance between imprinted genes (increased IGF2 and diminished $H_{19}$ and P57KIP2) gives rise to the increase in proliferation of $\beta$-cells, a striking feature of focal adenomatous hyperplasia not observed in the diffuse form. ${ }^{128}$ H19 seems directly or indirectly to modulate cytoplasmic levels of the product of the IGF2 allele and thus the H19 gene seems to be an antagonist to IGF2 in trans. ${ }^{128}$ Figure 5 illustrates the genetic aetiology of a focal lesion.

The probability for this somatic chromosomal event occurring in a fetus carrying a heterozygous mutation of $A B C C 8 /$ KCNJ11 of paternal origin is about $1 \% .{ }^{128}$ Recently it was demonstrated that individual patients with focal CHI may have more than one focal pancreatic lesion due to separate somatic maternal deletion of the $11 \mathrm{p} 15$ region $^{137}$ and that some focal lesions have a duplication of the paternal allele on chromosome $11 .{ }^{129}$

\section{SUMMARY}

CHI is a major cause of hypoglycaemia in the newborn and infancy period. So far mutations in seven different genes have been reported which lead to dysregulated insulin secretion. Recent advances have identified the molecular basis of exercise induced CHI (due to mutations in SLC16A1) and highlighted the intriguing link between transient (or persistent $\mathrm{HH}$ ) and maturity onset diabetes of the young (due to mutations in $H N F 4 A$ ). Rapid genetic analysis for mutations in ABCC8 and KCNJ11 can be used as a powerful tool for differentiating between focal and diffuse disease in some patients and thus aid in patient management. Further genetic studies are required to understand the molecular basis of $\mathrm{CHI}$ in patients where no mutations are found in the genes described so far.

Competing interests: None declared

\section{REFERENCES}

1. Stanley CA. Hyperinsulinism in infants and children. Pediatr Clin North Am 1997:44:363-74.

2. Hussain K, Blankenstein O, De Lonlay P, Christesen HT. Hyperinsulinaemic hypoglycaemia: biochemical basis and the importance of maintaining normoglycaemia during management. Arch Dis Child 2007;92:568-70.

3. Bruninig GJ. Recent advances in hyperinsulinism and the pathogenesis of diabetes mellitus. Curr Opin Pediatr 1990;2:758-65.

4. Fournet JC, Junien C. The genetics of neonatal hyperinsulinism. Horm Res 2003; 59:30-4.

5. Glaser B, Thornton PS, Otonkoski T, Junien C. The genetics of neonatal hyperinsulinism. Arch Dis Child 2000;82:79-86.

6. de Lonlay P, Fournet JC, Touati G, Groos MS, Martin D, Sevin C, Delagne V, Mayaud C, Chigot V, Sempoux C, Brusset MC, Laborde K, Bellane-Chantelot C, Vassault A, Rahier J, Junien C, Brunelle F, Nihoul-Fékété C, Saudubray JM, Robert JJ. Heterogeneity of persistent hyperinsulinaemic hypoglycaemia. A series of 175 cases. Eur J Pediatr 2002;161:37-48.

7. Meissner T, Mayatepek E. Clinical and genetic heterogeneity in congenital hyperinsulinism. Eur J Pediatr 2002;161:6-20.

8. Sempoux C, Guiot Y, Lefevre A, Nihoul-Fekete C, Jaubert F, Saudubray JM, Rahier J. Neonatal hyperinsulinemic hypoglycemia: heterogeneity of the syndrome and keys for differential diagnosis. J Clin Endocrinol Metab 1998;83:1455-61.

9. Nestorowicz A, Glaser B, Wilson BA, Shyng SL, Nichols CG, Stanley CA, Thornton PS, Permutt MA. Genetic heterogeneity in familial hyperinsulinism. Hum Mol Genet 1998; 7:1119-28

10. Thomas $\mathbf{P}, \mathrm{Ye} Y$, Lightner $\mathbf{E}$. Mutation of the pancreatic islet inward rectifier Kir6.2 also leads to familial persistent hyperinsulinemic hypoglycemia of infancy. Hum Mol Genet 1996;5:1809-12.

11. Thomas PM, Cote GJ, Wohllk N, Haddad B, Mathew PM, Rabl W, Aguilar-Bryan L, Gagel RF, Bryan J. Mutations in the sulfonylurea receptor gene in familial persistent hyperinsulinemic hypoglycemia of infancy. Science 1995;268:426-9.

12. Nestorowicz A, Inagaki N, Gonoi T, Schoor KP, Wilson BA, Glaser B, Landau H, Stanley CA, Thornton PS, Seino S, Permutt MA. A nonsense mutation in the inward rectifier potassium channel gene, Kir6.2, is associated with familial hyperinsulinism. Diabetes 1997; 46:1743-8.

13. Dunne MJ, Kane C, Shepherd RM, Sanchez JA, James RF, Johnson PR, AynsleyGreen A, Lu S, Clement JP IV, Lindley KJ, Seino S, Aguilar-Bryan L. Familial persistent hyperinsulinemic hypoglycemia of infancy and mutations in the sulfonylurea receptor. N Engl J Med 1997;336:703-6.

14. Otonkoski T, Ammala C, Huopio H, Cote GJ, Chapman J, Cosgrove K, Ashfield R, Huang E, Komulainen J, Ashcroft FM, Dunne MJ, Kere J, Thomas PM. A point mutation inactivating the sulfonylurea receptor causes the severe form of persistent hyperinsulinemic hypoglycemia of infancy in Finland. Diabetes 1999;48:408-15.

15. Tanizawa Y, Matsuda K, Matsuo M, Ohta Y, Ochi N, Adachi M, Koga M, Mizuno S, Kajita M, Tanaka Y, Tachibana K, Inoue H, Furukawa S, Amachi T, Ueda K, Oka Y. Genetic analysis of Japanese patients with persistent hyperinsulinemic hypoglycemia of infancy: nucleotide-binding fold-2 mutation impairs cooperative binding of adenine nucleotides to sulfonylurea receptor 1. Diabetes 2000;49:114-20.

16. Marthinet E, Bloc A, Oka Y, Tanizawa Y, Wehrle-Haller B, Bancila V, Dubuis JM, Philippe J, Schwitzgebel VM. Severe congenital hyperinsulinism caused by a mutation in the Kir6.2 subunit of the adenosine triphosphate-sensitive potassium channel impairing trafficking and function. J Clin Endocrinol Metab 2005:90:5401-6. 
17. Tornovsky S, Crane A, Cosgrove KE, Hussain K, Lavie J, Heyman M, Nesher Y, Kuchinski N, Ben-Shushan E, Shatz O, Nahari E, Potikha T, Zangen D, TenenbaumRakover Y, de Vries L, Argente J, Gracia R, Landau H, Eliakim A, Lindley K, Dunne MJ, Aguilar-Bryan L, Glaser B. Hyperinsulinism of infancy: novel ABCC8 and KCNJ11 mutations and evidence for additional locus heterogeneity. J Clin Endocrinol Metab 2004;89:6224-34.

18. Ashcroft FM, Harrison DE, Ashcroft SJ. Glucose induces closure of single potassium channels in isolated rat pancreatic beta-cells. Nature 1984;312:446-8.

19. Clayton PT, Eaton S, Aynsley-Green A, Edginton M, Hussain K, Krywawych S, Datta V, Malingre HE, Berger R, van den Berg IE. Hyperinsulinism in short-chain L-3hydroxyacyl-CoA dehydrogenase deficiency reveals the importance of beta-oxidation in insulin secretion. J Clin Invest 2001;108:457-65.

20. Hussain K, Clayton PT, Krywawych S, Chatziandreou I, Mills P, Ginbey DW, Geboers AJ, Berger R, van den Berg IE, Eaton S. Hyperinsulinism of infancy associated with a novel splice site mutation in the SCHAD gene. J Pediatr 2005;146:706-8.

21. Molven A, Matre GE, Duran M, Wanders RJ, Rishaug U, Njolstad PR, Jellum E, Sovik 0 . Familial hyperinsulinaemic hypoglycemia caused by a defect in the SCHAD enzyme of mitochondrial fatty acid oxidation. Diabetes 2004;53:221-7.

22. Huopio H, Reimann F, Ashfield R, Komulainen J, Lenko HL, Rahier J, Vauhkonen I, Kere J, Laakso M, Ashcroft F, Otonkoski T. Dominantly inherited hyperinsulinism caused by a mutation in the sulfonylurea receptor type 1. J Clin Invest 2000;106:897-906.

23. Thornton PS, MacMullen C, Ganguly A, Ruchelli E, Steinkrauss L, Crane A, AguilarBryan L, Stanley CA. Clinical and molecular characterization of a dominant form of congenital hyperinsulinism caused by a mutation in the high-affinity sulfonylurea receptor. Diabetes 2003;52:2403-10.

24. Pinney SE, MacMullen C, Becker S, Lin YW, Hanna C, Thornton P, Ganguly A Shyng SL, Stanley CA. Clinical characteristics and biochemical mechanisms of congenital hyperinsulinism associated with dominant KATP channel mutations. J Clin Invest 2008;118:2877-86.

25. Lin YW, Macmullen C, Ganguly A, Stanley CA, Shyng SL. A novel KCNJ11 mutation associated with congenital hyperinsulinism reduces the intrinsic open probability of beta-cell ATP-sensitive potassium channels. J Biol Chem 2006;281:3006-12.

26. Stanley CA, Lieu YK, Hsu BYL, Burlina AB, Greenberg CR, Hopwood NJ, Perlman K, Rich BH, Zammarchi E, Poncz M. Hyperinsulinism and hyperammonemia in infants with regulatory mutations of the glutamate dehydrogenase gene. N Engl J Med 1998:338:1352-7

27. Stanley CA, Fang J, Kutyna K, Hsu BY, Ming JE, Glaser B, Poncz M. Molecular basis and characterization of the hyperinsulinism/hyperammonemia syndrome: predominance of mutations in exons 11 and 12 of the glutamate dehydrogenase gene. Diabetes 2000;49:667-73.

28. Yorifuji T, Muroi J, Uematsu A, Hiramatsu H, Momoi T. Hyperinsulinism hyperammonemia syndrome caused by mutant glutamate dehydrogenase accompanied by novel enzyme kinetics. Hum Genet 1999;104:476-9.

29. Miki Y, Taki T, Ohura T, Kato H, Yanagisawa M, Hayashi Y. Novel missense mutations in the glutamate dehydrogenase gene in the congenital hyperinsulinism hyperammonemia syndrome. J Pediatr 2000;136:69-72.

30. Santer R, Kinner M, Passarge M, Superti-Furga A, Mayatepek E, Meissner T, Schneppenheim R, Schaub J. Novel missense mutations outside the allosteric domain of glutamate dehydrogenase are prevalent in European patients with the congenital hyperinsulinism-hyperammonemia syndrome. Hum Genet 2001;108:66-71.

31. Fujioka H, Okano Y, Inada H, Asada M, Kawamura T, Hase Y, Yamano T. Molecular characterisation of glutamate dehydrogenase gene defects in Japanese patients with congenital hyperinsulinism/hyperammonaemia. Eur J Hum Genet 2001:9:931-7.

32. Glaser B, Kesavan P, Heyman M, Davis E, Cuesta A, Buchs A, Stanley CA, Thornton PS, Permutt MA, Matschinsky FM, Herold KC. Familial hyperinsulinism caused by an activating glucokinase mutation. N Engl J Med 1998;338:226-30.

33. Christesen HB, Jacobsen BB, Odili S, Buettger C, Cuesta-Munoz A, Hansen T, Brusgaard K, Massa O, Magnuson MA, Shiota C, Matschinsky FM, Barbetti F. The second activating glucokinase mutation (A456V): implications for glucose homeostasis and diabetes therapy. Diabetes 2002;51:1240-6.

34. Gloyn AL, Noordam K, Willemsen MA, Ellard S, Lam WW, Campbell IW, Midgley P, Shiota C, Buettger C, Magnuson MA, Matschinsky FM, Hattersley AT. Insights into the biochemical and genetic basis of glucokinase activation from naturally occurring hypoglycemia mutations. Diabetes 2003;52:2433-40.

35. Cuesta-Munoz AL, Huopio H, Otonkoski T, Gomez-Zumaquero JM, Nanto-Salonen K, Rahier J, Lopez-Enriquez S, Garcia-Gimeno MA, Sanz P, Soriguer FC, Laakso M. Severe Persistent Hyperinsulinemic Hypoglycemia due to a De Novo Glucokinase Mutation. Diabetes 2004;53:2164-8

36. Dullaart RP, Hoogenberg K, Rouwe CW, Stulp BK. Family with autosomal dominant hyperinsulinism associated with A456V mutation in the glucokinase gene. Journal of Internal Medicine 2004;255:143-5.

37. Wabitsch M, Lahr G, Van de Bunt M, Marchant C, Lindner M, von Puttkamer J Fenneberg A, Debatin KM, Klein R, Ellard S, Clark A, Gloyn AL. Heterogeneity in disease severity in a family with a novel G68V GCK activating mutation causing persistent hyperinsulinaemic hypoglycaemia of infancy. Diabet Med 2007;24:1393-9.

38. Christesen HB, Tribble ND, Molven A, Siddiqui J, Sandal T, Brusgaard K, Ellard S, Njølstad PR, Alm J, Brock Jacobsen B, Hussain K, Gloyn AL. Activating glucokinase (GCK) mutations as a cause of medically responsive congenital hyperinsulinism: prevalence in children and characterisation of a novel GCK mutation. Eur J Endocrinol 2008:159:27-34.
39. Pearson ER, Boj SF, Steele AM, Barrett T, Stals K, Shield JP, Ellard S, Ferrer J, Hattersley AT. Macrosomia and hyperinsulinaemic hypoglycaemia in patients with heterozygous mutations in the HNF4A gene. PLoS Med 2007;4:e118.

40. Fajans SS, Bell Gl. Macrosomia and neonatal hypoglycaemia in RW pedigree subjects with a mutation (Q268X) in the gene encoding hepatocyte nuclear factor 4alpha (HNF4A). Diabetologia 2007;50:2600-1.

41. Kapoor R, Locke J, Colclough K, Wales J, Conn J, Ellard S, Hussain K. Persistent Hyperinsulinaemic Hypoglycaemia and Maturity Onset Diabetes of the Young (MODY) due to Heterozygous HNF4A Mutations. Diabetes 2008;57:1659-63.

42. Otonkoski T, Jiao H, Kaminen-Ahola N, Tapia-Paez I, Ullah MS, Parton LE, Schuit F Quintens R, Sipila I, Mayatepek E, Meissner T, Halestrap AP, Rutter GA, Kere J. Physical exercise-induced hypoglycemia caused by failed silencing of monocarboxylate transporter 1 in pancreatic beta cells. Am J Hum Genet 2007;81:467-74.

43. Fournet JC, Junien C. Genetics of congenital hyperinsulinism. Endocr Pathol 2004;15:233-40

44. Someya T, Miki T, Sugihara S, Minagawa M, Yasuda T, Kohno Y, Seino S. Characterization of genes encoding the pancreatic $\beta$-cell ATP-sensitive $\mathrm{K}^{+}$channel in persistent hyperinsulinemic hypoglycemia of infancy in Japanese patients. Endocr $\mathrm{J}$ 2000; 47:715-22.

45. Rahier J, Guiot Y, Sempoux C. Persistent hyperinsulinaemic hypoglycaemia of infancy: a heterogeneous syndrome unrelated to nesidioblastosis. Arch Dis Child Fetal Neonatal Ed 2002;82:F108-12.

46. Hussain K, Flanagan SE, Smith W, Ashworth M, Day M, Pierro A, Ellard S. An ABCC8 gene mutation and mosaic uniparental isodisomy resulting in atypical diffuse congenital hyperinsulinism. Diabetes 2008;57:259-63.

47. Kapoor R, James C, Hussain K. Advances in the diagnosis and management of hyperinsulinaemic hypoglycaemia. Nat Clin Pract Endocrinol Metab 2009;5:101-12.

48. Peranteau WH, Ganguly A, Steinmuller L, Thornton P, Johnson MP, Howell LJ, Stanley CA, Adzick NS. Prenatal diagnosis and postnatal management of diffuse congenital hyperinsulinism: a case report. Fetal Diagn Ther 2006;21:515-8.

49. Seino S, Miki T. Physiological and pathophysiological roles of ATP-sensitive $\mathrm{K}_{+}$ channels. Prog Biophys Mol Biol 2003:81:133-76.

50. Ashcroft FM. ATP-sensitive potassium channelopathies: focus on insulin secretion J Clin Invest 2005:115:2047-58.

51. Ashcroft FM. Adenosine 5'-triphosphate-sensitive potassium channels. Annu Rev Neurosci 1988;11:97-118.

52. Inagaki N, Gonoi T, Clement JP 4th, Namba N, Inazawa J, Gonzalez G, AguilarBryan L, Seino S, Bryan J. Reconstitution of KATP: An inward rectifier subunit plus the sulphonylurea receptor. Science 1995;270:1166-70.

53. Tucker SJ, Gribble FM, Proks P, Trapp S, Ryder TJ, Haug T, Reimann F, Ashcroft FM. Molecular determinants of K-ATP channel inhibition by ATP. EMBO J 1998;17:3290-6.

54. Aguilar-Bryan L, Bryan J. Molecular biology of adenosine triphosphate-sensitive potassium channels. Endocr Rev 1999;20:101-35.

55. Heron L, Virsolvy A, Peyrollier K, Gribble FM, Le Cam A, Ashcroft FM, Bataille D. Human $\alpha$-endosulfine, a possible regulator of sulfonylurea-sensitive $K_{\text {ATP }}$ channel: Molecular cloning, expression and biological properties. Proc Natl Acad Sci 1998;95:8387-91.

56. Conti LR, Radeke CM, Shyng SL, Vandenberg CA. Transmembrane topology of the sulfonylurea receptor SUR1. J Biol Chem 2001:276:41270-8.

57. Ueda K, Komine J, Matsuo M, Seino S, Amachi T. Cooperative binding of ATP and MgADP in the sulfonylurea receptor is modulated by glibenclamide. Proc Natl Acad Sci USA 1999;96:1268-72

58. Matsuo M, Kimura Y, Ueda K. KATP channel interaction with adenine nucleotides J Mol Cell Cardiol 2005:38:907-16.

59. Zerangue $\mathbf{N}$, Schwappach B, Jan YN, Jan LY. A new ER trafficking signal regulates the subunit stoichiometry of plasma membrane K(ATP) channels. Neuron 1999;22:537-48.

60. Tucker SJ, Gribble FM, Zhao C, Trapp S, Ashcroft FM. Truncation of Kir6.2 produces ATP-sensitive $\mathrm{K}+$ channels in the absence of the sulphonylurea receptor. Nature 1997;387:179-83.

61. Sharma N, Crane A, Clement JPt, Gonzalez G, Babenko AP, Bryan J, Aguilar-Bryan $\mathrm{L}$. The $\mathrm{C}$ terminus of SUR1 is required for trafficking of KATP channels. J Biol Chem 1999;274:20628-32.

62. Babenko AP, Aguilar-Bryan L, Bryan J. A view of sur/KIR6.X, KATP channels. Annu Rev Physiol 1998;60:667-87.

63. Clement JP 4th, Kunjilwar K, Gonzalez G, Schwanstecher M, Panten U, AguilarBryan L, Bryan J. Association and stoichiometry of K(ATP) channel subunits. Neuron 1997; 18:827-38

64. Aguilar-Bryan L, Clement JP IV, Gonzalez G, Kunjilwar K, Babenko A, Bryan J. Toward understanding the assembly and structure of $\mathrm{K}_{\text {ATP }}$ channels. Physiol Rev 1998; 78:227-45

65. Inagaki N, Gonoi T, Clement JP, Wang CZ, Aguilar-Bryan L, Bryan J, Seino S. A family of sulfonylurea receptors determines the pharmacological properties of ATPsensitive K+ channels. Neuron 1996;16:1011-17.

66. Aguilar-Bryan L, Nichols GC, Wechsler WS, Clement JP IV, Boyd AE III, Gonzalez G, Herrers-Sosa E, Nguy K, Bryan J, Nelson DA. Cloning of the beta cell high-affinity sulfonylurea receptor: a regulator of insulin secretion. Science 1995:268:423-6.

67. Bitner-Glindzicz M, Lindley KJ, Rutland P, Blaydon D, Smith WV, Milla PJ, Hussain K, Furth-Lavi J, Cosgrove KE, Shepherd RM, Barnes PD, O'Brien RE, Farndon PA, Sowden J, Liu XZ, Scanlon MJ, Malcolm S, Dunne MJ, Aynsley-Green A, Glaser B. 
A recessive contiguous gene deletion causing infantile hyperinsulinism, enteropathy and deafness identifies the Usher Type 1C gene. Nat Gene 2000;26:56-60.

68. Fernández-Marmiesse A, Salas A, Vega A, Fernández-Lorenzo JR, Barreiro J, Carracedo A. Mutation spectra of ABCC8 gene in Spanish patients with Hyperinsulinism of Infancy (HI). Hum Mutat 2006;27:214.

69. Flanagan SE, Clauin S, Bellanné-Chantelot C, de Lonlay P, Harries LW, Gloyn AL, Ellard S. Update of mutations in the genes encoding the pancreatic beta-cell K(ATP) channel subunits Kir6.2 (KCNJ11) and sulfonylurea receptor 1 (ABCC8) in diabetes mellitus and hyperinsulinism. Hum Mutat 2009:30:170-80.

70. Dekel B, Lubin D, Modan-Moses D, Quint J, Glaser B, Meyerovitch J. Compound heterozygosity for the common sulfonylurea receptor mutations can cause mild diazoxide-sensitive hyperinsulinism. Clin Pediatr (Phila) 2002:41:183-6.

71. Muzyamba M, Farzaneh T, Behe P, Thomas A, Christesen HB, Brusgaard K, Hussain K, Tinker A. Complex ABCC8 DNA variations in congenital hyperinsulinism: lessons from functional studies. Clin Endocrinol (Oxf) 2007;67:115-24.

72. Crane A, Aguilar-Bryan L. Assembly, maturation, and turnover of K(ATP) channel subunits. J Biol Chem 2004;279:9080-90.

73. Cartier EA, Conti LR, Vandenberg CA, Shyng SL. Defective trafficking and function of $\mathrm{K}_{\text {ATP }}$ channels caused by a sulfonylurea receptor 1 mutation associated with persistent hyperinsulinemic hypoglycemia of infancy. Proc Natl Acad Sci USA 2001;98:2882-7.

74. Partridge CJ, Beech DJ, Sivaprasadarao A. Identification and pharmacologica correction of a membrane trafficking defect associated with a mutation in the sulfonylurea receptor causing familial hyperinsulinism. J Biol Chem 2001:276:35947-52.

75. Shyng SL, Ferrigni T, Shepard JB, Nestorowicz A, Glaser B, Permutt MA, Nichols CG. Functional analyses of novel mutations in the sulfonylurea receptor 1 associated with persistent hyperinsulinemic hypoglycemia of infancy. Diabetes 1998;47:1145-51.

76. Taschenberger G, Mougey A, Shen S, Lester LB, LaFranchi S, Shyng SL. Identification of a familial hyperinsulinism-causing mutation in the sulfonylurea receptor 1 that prevents normal trafficking and function of KATP channels. $J$ Biol Chem 2002;277:7139-46.

77. Matsuo M, Trapp S, Tanizawa Y, Kioka N, Amachi T, Oka Y, Ashcroft FM, Ueda K. Functional analysis of a mutant sulfonylurea receptor, SUR1-R1420C, that is responsible for persistent hyperinsulinemic hypoglycemia of infancy. J Biol Chem 2000;275:41184-91.

78. Nichols CG, Shyng SL, Nestorowicz A, Glaser B, Clement JP 4th, Gonzalez G, Aguilar-Bryan L, Permutt MA, Bryan J. Adenosine diphosphate as an intracellular regulator of insulin secretion. Science 1996;272:1785-7.

79. Branstrom R, Leibiger IB, Leibiger B, Corkey BE, Berggren PO, Larsson O. Long chain coenzyme A esters activate the pore-forming subunit (Kir6. 2) of the ATPregulated potassium channel. J Biol Chem 1998;273:31395-400.

80. Deloukas $\mathbf{P}$, Dauwerse JG, Moschonas NK, van Ommen GJ, van Loon AP. Three human glutamate dehydrogenase genes (GLUD1, GLUDP2, and GLUDP3) are located on chromosome 10q, but are not closely physically linked. Genomics 1993;17:676-81.

81. Hudson RC, Daniel RM. L-glutamate dehydrogenases: distribution, properties and mechanism. Comp Biochem Physiol B 1993;106:767-92.

82. Kelly A, Li C, Gao Z, Stanley CA, Matschinsky FM. Glutaminolysis and Insulin Secretion: From Bedside to Bench and Back. Diabetes 2002;51:S421-6.

83. Fahien LA, MacDonald MJ, Kmiotek EH, Mertz RJ, Fahien CM. Regulation of insulin release by factors that also modify glutamate dehydrogenase. J Biol Chem 1980;263:13610-14

84. Weinzimer SA, Stanley CA, Berry GT, Yudkoff M, Tuchman M, Thornton PS. A syndrome of congenital hyperinsulinism and hyperammonemia. J Pediatr 1997:130:661-4.

85. Zammarchi E, Filippi L, Novembre E, Donati MA. Biochemical evaluation of a patient with a familial form of leucine-sensitive hypoglycemia and concomitant hyperammonemia. Metabolism 1996:45:957-60.

86. Stanley CA. Hyperinsulinism/hyperammonemia syndrome: insights into the regulatory role of glutamate dehydrogenase in ammonia metabolism. Mol Genet Metab 2004:81:S45-51.

87. Raizen DM, Brooks-Kayal A, Steinkrauss L, Tennekoon GI, Stanley CA, Kelly A. Central nervous system hyperexcitability associated with glutamate dehydrogenase gain of function mutations. J Pediatr 2005;146:388-94.

88. MacMullen C, Fang J, Hsu BY, Kelly A, de Lonlay-Debeney P, Saudubray JM, Ganguly A, Smith TJ, Stanley CA, Hyperinsulinism/hyperammonemia Contributing Investigators. Hyperinsulinism/hyperammonemia syndrome in children with regulatory mutations in the inhibitory guanosine triphosphate-binding domain of glutamate dehydrogenase. J Clin Endocrinol Metab 2001;86:1782-7.

89. Iynedjian PB, Möbius G, Seitz HJ, Wollheim CB, Renold AE. Tissue-specific expression of glucokinase: identification of the gene product in liver and pancreatic islets. Proc Natl Acad Sci USA 1986;83:1998-2001.

90. Matschinsky FM. Regulation of pancreatic beta-cell glucokinase: from basics to therapeutics. Diabetes 2002:51:S394-404.

91. Zelent D, Najafi H, Odili S, Buettger C, Weik-Collins H, Li C, Doliba N, Grimsby J, Matschinsky FM. Glucokinase and glucose homeostasis: proven concepts and new ideas. Biochem Soc Trans 2005;33:306-10.

92. Ralph EC, Thomson J, Almaden J, Sun S. Glucose modulation of glucokinase activation by small molecules. Biochemistry 2008:47:5028-36.

93. Heredia VV, Carlson TJ, Garcia E, Sun S. Biochemical basis of glucokinase activation and the regulation by glucokinase regulatory protein in naturally occurring mutations. J Biol Chem 2006:281:40201-7.
94. Van de Bunt M, Edghill ML, Hussain K, Ellard S, Gloyn A. Gene duplications resulting in over expression of glucokinase are not a common cause of hypoglycaemia of infancy in humans. Mol Genet Metab 2008;94:268-9.

95. Christesen HB, Brusgaard K, Beck Nielsen H, Brock Jacobsen B. Non-insulinoma persistent hyperinsulinaemic hypoglycaemia caused by an activating glucokinase mutation: hypoglycaemia unawareness and attacks. Clin Endocrinol (Oxf) 2008;68:1011.

96. Vredendaal PJ, van den Berg IE, Malingré HE, Stroobants AK, Olde Weghuis DE, Berger Human short-chain L-3-hydroxyacyl-CoA dehydrogenase: cloning and characterization of the coding sequence. Biochem Biophys Res Commun 1996;223:718-23

97. Vredendaal PJ, van den Berg IE, Stroobants AK, van der A DL, Malingré HE, Berger R. Structural organization of the human short-chain L-3-hydroxyacyl-CoA dehydrogenase gene. Mamm Genome 1998;9:763-8

98. Hardy OT, Hohmeier HE, Becker TC, Manduchi E, Doliba NM, Gupta RK, White P, Stoeckert CJ Jr, Matschinsky FM, Newgard CB, Kaestner KH. Functional genomics of the beta-cell: short-chain 3-hydroxyacyl-coenzyme A dehydrogenase regulates insulin secretion independent of $\mathrm{K}+$ currents. Mol Endocrinol 2007;21:765-73.

99. Martens GA, Vervoort A, Van de Casteele M, Stangé G, Hellemans K, Van Thi HV, Schuit F, Pipeleers D. Specificity in beta cell expression of L-3-hydroxyacyl-CoA dehydrogenase, short chain, and potential role in down-regulating insulin release. $J$ Biol Chem 2007;282:21134-44.

100. Lantz KA, Vatamaniuk MZ, Brestelli JE, Friedman JR, Matschinsky FM, Kaestner $\mathrm{KH}$. Foxa2 regulates multiple pathways of insulin secretion. J Clin Invest 2004; 14:512-20.

101. Sund NJ, Vatamaniuk MZ, Casey M, Ang SL, Magnuson MA, Stoffers DA Matschinsky FM, Kaestner KH. Tissue-specific deletion of Foxa2 in pancreatic beta cells results in hyperinsulinemic hypoglycemia. Genes Dev 2001;15:1706-15.

102. Meissner T, Otonkoski T, Feneberg R, Beinbrech B, Apostolidou S, Sipilä I, Schaefer F, Mayatepek E. Exercise induced hypoglycaemic hyperinsulinism. Arch Dis Child 2001:84:254-7.

103. Meissner T, Friedmann B, Okun JG, Schwab MA, Otonkoski T, Bauer T, Bärtsch P, Mayatepek E. Massive insulin secretion in response to anaerobic exercise in exercise-induced hyperinsulinism. Horm Metab Res 2005:37:690-4.

104. Halestrap AP, Price NT. The proton-linked monocarboxylate transporter (MCT) family: structure, function and regulation. Biochem J 1999;343:281-99.

105. Cuff MA, Shirazi-Beechey SP. The human monocarboxylate transporter, MCT1 genomic organization and promoter analysis. Biochem Biophys Res Commun 2002;292:1048-56.

106. Garcia CK, Li X, Luna J, Francke U. cDNA cloning of the human monocarboxylate transporter 1 and chromosomal localization of the SLC16A1 locus to 1p13.2-p12. Genomics 1994:23:500-3.

107. Zhao C, Rutter GA. Overexpression of lactate dehydrogenase A attenuates glucoseinduced insulin secretion in stable MIN-6 beta-cell lines. FEBS Lett 1998;430:213-6.

108. Ishihara $\mathbf{H}$, Wang $H$, Drewes $L R$, Wollheim CB. Overexpression of monocarboxylate transporter and lactate dehydrogenase alters insulin secretory responses to pyruvate and lactate in beta cells. J Clin Invest 1999;104:1621-9.

109. Otonkoski T, Kaminen N, Ustinov J, Lapatto R, Meissner T, Mayatepek E, Kere J Sipilä I. Physical exercise-induced hyperinsulinemic hypoglycemia is an autosomaldominant trait characterized by abnormal pyruvate-induced insulin release. Diabetes 2003;52(1):199-204

110. Duncan SA, Navas MA, Dufort D, et al. Regulation of a transcription factor network required for differentiation and metabolism. Science 1998:281:692-5.

111. Sladek FM, Zhong WM, Lai E, Darnell JE Jr. Liver-enriched transcription factor HNF-4 is a novel member of the steroid hormone receptor superfamily. Genes Dev 1990:4(12B):2353-65.

112. Boj SF, Parrizas M, Maestro MA, Ferrer J. A transcription factor regulatory circuit in differentiated pancreatic cells. Proc Natl Acad Sci USA 2001;98:14481-6.

113. Odom DT, Zizlsperger N, Gordon DB, Bell GW, Rinaldi NJ, Murray HL, Volkert TL, Schreiber J, Rolfe PA, Gifford DK, Fraenkel E, Bell GI, Young RA. Control of pancreas and liver gene expression by HNF transcription factors. Science 2004;303:1378-81.

114. Wang H, Maechler P, Antinozzi PA, Hagenfeldt KA, Wollheim CB. Hepatocyte nuclear factor 4 alpha regulates the expression of pancreatic beta-cell genes implicated in glucose metabolism and nutrient-induced insulin secretion. J Biol Chem 2000;275:35953-9.

115. Hadzopoulou-Cladaras M, Kistanova E, Evagelopoulou C, Zeng S, Cladaras C Ladias JAA. Functional domains of the nuclear receptor hepatocyte nuclear factor 4 $\mathrm{J}$ Biol Chem 1997;272:539-50.

116. Thomas H, Jaschkowitz K, Bulman M, Frayling TM, Mitchell SM, Roosen S, LingottFrieg A, Tack CJ, Ellard S, Ryffel GU, Hattersley AT. A distant upstream promoter of the HNF-4alpha gene connects the transcription factors involved in maturity-onset diabetes of the young. Hum Mol Genet 2001;10:2089-97.

117. Yamagata K, Furuta H, Oda N, Kaisaki P, Menzel S, Cox NJ, Fajans SS, Signorini S Stoffel M, Bell Gl. Mutations in the hepatocyte nuclear factor-4alpha gene in maturity-onset diabetes of the young (MODY1). Nature 1996:384:458-60.

118. Stoffel M, Duncan SA. The maturity-onset diabetes of the young (MODY1) transcription factor HNF4alpha regulates expression of genes required for glucose transport and metabolism. Proc Natl Acad Sci USA 1997;94:13209-14.

119. Gupta RK, Vatamaniuk MZ, Lee CS, Flaschen RC, Fulmer JT, Matschinsky FM, Duncan SA, Kaestner KH. The MODY1 gene HNF-4alpha regulates selected genes involved in insulin secretion. J Clin Invest 2005;115:1006-15.

120. Miura A, Yamagata K, Kakei M, Hatakeyama H, Takahashi N, Fukui K, Nammo T, Yoneda K, Inoue Y, Sladek FM, Magnuson MA, Kasai H, Miyagawa J, Gonzalez FJ, 
Shimomura I. Hepatocyte nuclear factor-4alpha is essential for glucose-stimulated insulin secretion by pancreatic beta-cells. J Biol Chem 2006;281:5246-57.

121. Rahier J, Guiot $Y$, Sempoux C. Persistent hyperinsulinaemic hypoglycaemia of infancy: a heterogeneous syndrome unrelated to nesidioblastosis. Arch Dis Child Fetal Neonatal Ed 2000;82:F108-12.

122. Goossens A, Gepts W, Saudubray JM, Bonnefont JP, Nihoul-Fekete, Heitz PU, Klöppel G. Diffuse and focal nesidioblastosis. A clinicopathological study of 24 patients with persistent neonatal hyperinsulinemic hypoglycemia. Am J Surg Pathol 1989:13:766-75.

123. Verkarre V, Fournet JC, de Lonlay P, Gross-Morand MS, Devillers M, Rahier J, Brunelle F, Robert JJ, Nihoul-Fekete C. Saudubray JM, Junien C. Paternal mutation of the sulfonylurea receptor (SUR1) gene and maternal loss of 11p15 imprinted genes lead to persistent hyperinsulinism in focal adenomatous hyperplasia. J Clin Invest 1998;102:1286-91.

124. de Lonlay P, Fournet JC, Rahier J, Gross-Morand MS, Poggi-Travert F, Foussier V, Bonnefont JP, Brusset MC, Brunelle F, Robert JJ, Nihoul-Fekete C, Saudubray JM, Junien $\mathrm{C}$. Somatic deletion of the imprinted $11 \mathrm{p} 15$ region in sporadic persistent hyperinsulinemic hypoglycemia of infancy is specific of focal adenomatous hyperplasia and endorses partial pancreatectomy. J Clin Invest 1997;100:802-7.

125. Glaser B, Ryan F, Donath M, Landau H, Stanley CA, Baker L, Barton DE, Thornton PS. Hyperinsulinism caused by paternal-specific inheritance of a recessive mutation in the sulfonylurea-receptor gene. Diabetes 1999;48:1652-7.

126. Ryan F, Devaney D, Joyce C, Nestorowicz A, Permutt MA, Glaser B, Barton DE, Thornton PS. Hyperinsulinism: molecular aetiology of focal disease. Arch Dis Child 1998;79:445-7.

127. Fournet JC, Mayaud C de Lonlay $\mathrm{P}$, Gross-Morand MS, Verkarre V Castanet $M$, Devillers M, Rahier J, Brunelle F, Robert JJ, Nihoul-Fekete C, Saudubray JM, Junien C. Unbalanced expression of 11 p15 imprinted genes in focal forms of congenital hyperinsulinism: association with a reduction to homozygosity of a mutation in ABCC8 or KCNJ11. Am J Pathol 2001;158:2177-84.

128. Fournet JC, Mayaud C, de Lonlay P, Verkarre V, Rahier J, Brunelle F, Robert JJ Nihoul-Fekete C, Saudubray JM, Junien C. Loss of imprinted genes and paternal
SUR1 mutations lead to focal form of congenital hyperinsulinism. Horm Res 2000:53:2-6.

129. Damaj L, le Lorch M, Verkarre V, Werl C, Hubert L, Nihoul-Fékété C, Aigrain Y, de Keyzer Y, Romana SP, Bellanne-Chantelot C, de Lonlay P, Jaubert F. Chromosome 11 15 Paternal Isodisomy in Focal Forms of Neonatal Hyperinsulinism. J Clin Endocrinol Metab 2008;93:4941-47.

130. Giannoukakis N, Deal C, Paquette J, Goodyer C, Polychronakos C. Parental genomic imprinting of the human IGF2 gene. Nat Genet 1993;4:98-101.

131. Lee MP, Hu R-J, Johnson LA, Feinberg AP. Human KVLQT1 gene shows tissuespecific imprinting and encompasses Beckwith-Wiedemann syndrome chromosomal rearrangements. Nat Genet 1997;15:181-5.

132. Matsuoka S, Edwards M, Bai C, Parker S, Zhang P, Baldini A, Harper J, Elledge S p57KIP2, a structurally distinct member of the p21CIP1 Cdk inhibitor family, is a candidate tumor suppressor gene. Genes Dev 1995;9:650-62.

133. Zhang Y, Tycko B. Monoallelic expression of the human H19 gene. Nat Genet 1992;1:40-4.

134. Hao Y, Crenshaw T, Moulton T, Newcomb E, Tycko B. Tumour-suppressor activity of H19 RNA. Nature 1993:365:764-7.

135. Hatada I, Inazawa J, Abe T, Nakayama M, Kaneko Y, Jinno Y, Niikawa N, Ohashi S Fukushima Y, lida K, Yutani C, Takahashi S, Chiba Y, Ohishi S, Mukai T. Genomic imprinting of human p57KIP2 and its reduced expression in Wilms' tumors. Hum Mol Genet 1996:5:783-8.

136. Guillemot F, Caspary T, Tilghman SM, Copeland NG, Gilbert DJ, Jenkins NA, Anderson DJ, Joyner AL, Rossant J, Nagy A. Genomic imprinting of Mash2, a mouse gene required for trophoblast development. Nat Genet 1995;9:235-42.

137. Giurgea I, Sempoux C, Bellanné-Chantelot C, Ribeiro M, Hubert L, Boddaert N, Saudubray JM, Robert JJ, Brunelle F, Rahier J, Jaubert F, Nihoul-Fékété C, de Lonlay P. The Knudson's two-hit model and timing of somatic mutation may account for the phenotypic diversity of focal congenital hyperinsulinism. J Clin Endocrinol Metab 2006;91:4118-23.

138. Chik KK, Chan CW, Lam CW, Ng KL. Hyperinsulinism and hyperammonaemia syndrome due to a novel missense mutation in the allosteric domain of the Glutamate dehydrogenase 1 gene. J Paediatr Child Health 2008;44:517-9.

\section{Take advantage of BMJ Journals' remarkable catalogue of titles with Related Collections}

No busy professional has time to browse through all pertinent journals to find relevant articles, but with Related Collections you no longer have to. Follow the "Related Collections" link from any article and use the "Show Collections from other Journals" to expand your search across all BMJ Journals. Or simply follow the "Browse by topic" link on the home page. By setting up your own collections and receiving email alerts every time an article is added to your chosen area, you can build up your own significant body of knowledge. 